\title{
KES VASTUTAB? LIKLUSÕNNETUSES OSALEJATE KEELELINE KONSTRUEERIMINE
}

\author{
Katrin Aava
}

Ülevaade. Liiklusõnnetuste kajastused sisaldavad ühiskondlikke hinnanguid selle kohta, milline tähendus on inimelul, roll ja vastutus osapooltel ning kelle süul asjad juhtuvad. Uuringus kasutatud kriitiline diskursuseanalüüs on meetod, mis võimaldab tuvastada selliseid tekstides varjatud ühiskondlikke kokkuleppeid ning tekstidesse kodeeritud eelistatavaid tõlgendusi. Mida näitab lingvistiline analüüs osasündmuste agentsuse, asjaolude esituse ja teksti vaatepunkti kohta ning kas need tulemused on kooskõlas lugejaarvamuse uurimusega? Selleks analüüsisin 2013. aasta oktoobris-novembris politsei edastatud 26 liiklusteadet õnnetuste kohta ülekäigurajal. Selgitamaks kujutatava sündmuse hoiakulise tõlgenduse sissekirjutamist teksti, küsitlesin 104 vastajat.

Liiklusteadete pealaused on passiivlaused ning sõnastatud lausesemantiliste tunnuste agentiivne/mitteagentiivne alusel juhtumitena (õnnetused toimuvad), mitte tegevuste, protsesside ega tegudena. Liiklusteadete esimese astme kõrvallauses on aktiivsed osalised jalakäija otsa sõitvad autod ning sõidukilt löögi saanud jalakäijad. Autojuhti nimetatakse teise astme kõrvallauses. Uudised on raamistatud juhi vaatepunktist. Selline uudiste raamistus on kooskõlas lugejaarvamuse uuringuga: lugejad interpreteerivad liiklusteateid autojuhile soodsamal viisil. Mida rohkem sõnastati asjaolusid, mille vastu eksis jalakäija (helkuri puudumine, tumedad riided) või mis segasid autojuhti ülekäigurajal (halb nähtavus), seda rohkem tajuti süüdlasena jalakäijat.

Võtmesõnad: kriitiline diskursuseanalüüs, raamistamine, vaatepunkt, liiklusteated 


\section{Lähtekohad ja eesmärk}

Liiklusuudised on olulised tekstid, mis sisaldavad ühiskonnale omast suhtluskultuuri ja väljakujunenud sotsiaalseid kokkuleppeid. Liiklusuudised annavad edasi sõnumeid selle kohta, milline tähendus on inimelul, milline roll ja vastutus on jalakäijal ja autojuhil. Nii väljenduvad liiklusuudistes ühiskonnas aktsepteeritud suhted. Teed on avaliku ruumi osa, kus kõigil kodanikel peaksid olema võrdsed õigused. Samas toimub erinevate huvigruppide võitlus selle eest, kes on tee kasutajana paremas positsioonis. Neid suhteid väljendatakse keeleliselt: nt kas jalakäijat ning ratturit nähakse liikluse segajana või loomuliku osana liiklusest.

Seniste uuringute põhjal domineerib liiklusõnnetuste diskursuses autokeskne lähenemine, kus rõhutatakse eelkõige suurte autode turvalisust (Freund, Martin 1997). Selline olukord jätab autota avalikus ruumis liiklejad halvemasse positsiooni. Autojuhikesksusel on ühiskonnas ka pikem kultuuriline ning ajalooline taust: kultuuriliselt on konstrueeritud head elu, mehelikkust ja ka võimu diskursust võimsate autode kaudu (Whatley 1988, Sheller, Urry 2000: 738). Lucie Vallières (2006) on uurinud Kanada näitel, kuidas neoliberaalsed poliitilismajanduslikud diskursused mõjutavad liiklusohutuse kampaaniaid, pannes vastutuse liiklusõnnetuse eest üksikindiviididele. Liikluskasvatus on suunatud sellele, et jalakäija ei tohi segada autosid, kujundades sedasi autokeskset liikluskultuuri.

Autotootjad on enda majandushuvide kaitseks mõjutanud seadusandlust, linnaplaneerijad on pikka aega tegutsenud selle nimel, et luua linnaruumis eelkõige autojuhtidele paremad tingimused. See väljendub ka keelekasutuses. Maailmapanga ja autotootjate koostöös valminud globaalse teedeohutuse partnerlusprogrammi sõnasagedusanalüüs (Roberts jt 2006) näitas, et dokumentides kasutatakse vähem sõnu nagu kiirus, kiiruspïrang, jalakäija, avalik transport, kõndimine, jalgrattasõit, eelistatumad väljendid on kool, kampaania, juhikoolitus, teavitus-, reklaamitahvel. Tähelepanu on juhitud ka ühendriikides viimastel aastatel toimunud keelelisele pöördele: jalakäija surmaga lõppenud õnnetustes saab õnnetuse põhjustaja süüdistuse hooletus juhtimises, mitte surma põhjustamises (Oatman-Stanford 2014).

Artikli fookuses olevate liiklusõnnetuste toimumispaigaks on ülekäigurada, mis on see osa teest, kus jalakäija peab saama turvaliselt teed ületada. Kehtiva liiklusseaduse (2010) § 2 defineerib liiklusõnnetuse legaalterminina: "liiklusõnnetus on juhtum, kus vähemalt ühe sõiduki teel liikumise või teelt väljasõidu tagajärjel saab inimene vigastada, surma või tekib varaline kahju”. § 35 kohaselt "[r]eguleerimata ülekäigurajale lähenedes peab juht sõitma sellise kiirusega, mis on piisavalt väike, et mitte ohustada jalakäijat, kes on astunud või astumas ülekäigurajale”. Liiklusseaduse kohaselt pole mingil põhjusel õigustatud ülekäigurajal sõiduteed ületajale otsasõit. Kas see väljendub ka tegelikult liiklussõnumites? Eesmärk on selgitada, millised suhted loomulikustatakse liiklusteadetes ning kelle vaatepunkti need esindavad?

Kriitilise tekstianalüüsi kohaselt pole keelekasutus neutraalne, kuna teksti koostaja esitab sõnumi kellegi vaatepunktist, mis teeb sündmuste objektiivse kirjeldamise võimatuks (Fairclough 1989). Diskursuse kord määrab, milline on ühes või teises kontekstis loomulik keelekasutus. Diskursus on sotsiaalne praktika, kommunikatsiooni viis teatud sotsiaalses, kultuurilises, ajaloolises, poliitilises situatsioonis (Dijk 2005: 3). Kriitilise tekstianalüüsi metodoloogiaga on tegelenud Norman Fairclough (1991, 1992, 1995, 2001, 2005), Ruth Wodak (1996), Fairclough 
ja Wodak 1997, Teun van Dijk (2005) jt. Kui diskursuseanalüüsi tehes kirjeldatakse keelekasutust, siis kriitilist diskursuseanalüüsi tehes selgitatakse ka keelekasutuse põhjuseid (Fairclough 1995: 43).

Kriitiline diskursuseanalüüs seob sotsiaalsed teooriad tekstianalüüsiga, analüüsis tuntakse huvi, kuidas tekstid toimivad suhtluses. Fairclough' (1992) järgi on diskursusel kolm mõõdet: kõneldud, kirjutatud keeletekst; diskursuslik käitumine, mis sisaldab teksti tootmist ja selle tõlgendamist, ning sotsiokultuuriline käitumine, mis hõlmab sotsiaalseid ja poliitilisi suhteid. Fairclough tegeles sotsiolingvistilise uurimusega, uurides teksti sõnavara, grammatikat, semantikat. Samuti uuris ta sotsiaalseid struktuure ning praktikaid, mis tekstidesse kirjutatakse.

Meediatekstide kriitilises diskursuseanalüüsis kasutatakse ka raamistamise mõistet (nt Serafini 2003 jt). Raamistamine annab võimaluse lisada oma tõlgendus hajusatele faktidele (McQuail 2000: 307). Uudiste diskursust käsitletakse sotsiokognitiivse protsessina, kus osalevad allikad, ajakirjanikud ning auditoorium, kes loovad ühiselt jagatud kultuuri, mis baseerub ühistele sotsiaalselt defineeritud rollidele (Pan, Kosicki 2010). Raamistamine on uudiste edastamise formaat, mille kohaselt lugu esitatakse ja ka tõlgendatakse ning see sisaldab hoiakuid sündmuste osalejate suhtes (Huckin 1997: 91-95). Diskursuseanalüüsis pööratakse kõigepealt tähelepanu esitatud info raamistamisele - valitud vaatenurgale, mis sisaldab teatud valikuid ja väärtustamist. Samuti võimaldab raamistamine selgitada kujutatava sündmuse hoiakulise tõlgenduse sissekirjutamist teksti. Raamistamiseks võib kasutada võtmesõnu, mis rõhutavad teatud seisukohti; mingite teemade, seisukohtade vm mainimata jätmist; teatud alternatiive sõnavalikul (Laherand 2008).

Peamised etteheited kriitilisele diskursuseanalüüsile on olnud järgmised: poliitilised ja sotsiaalsed ideoloogiad "loetakse" andmetesse sisse; sotsiaalsed ja keeleteooriad on meetodis tasakaalustamata; kriitilist diskursuseanalüüsi on tihti lahutatud sotsiaalsest kontekstist (Flowerdew 1999, Widdowson 1998). Et kontrollida kvalitatiivselt saadud tekstianalüüsi tulemuste usaldusväärsust kvantitatiivselt, kasutan artiklis trianguleerimismeetodit (Harvey, Macdonald 1993). Kombineerin kvalitatiivuurimuse kujundustüüpe kvantitatiivsete argumentidega, nii on lingvistiline analüüs ühendatud lugejaarvamuse uurimusega.

Analüüsin, kuidas tekstides kirjeldatakse sündmuste osapooli, konflikti ohvreid ja süüdlasi, kuidas tähistatakse sündmuste tegelasi ja millise tähenduse selline raamistamine teksti lugeja jaoks loob. Otsin vastust uurimisküsimustele: mida näitab lingvistiline analüüs sündmuste agentsuse, asjaolude esituse ja teksti vaatepunkti kohta, ning kas need tulemused on kooskõlas lugejaarvamuse uurimusega?

\section{Materjal ja meetod}

Uuring koosneb kahest etapist. Selgitamaks, kuidas konstrueeritakse liiklusteadetes osalejate rollid, uurin, kuidas nimetatakse tegevuses osalejaid, väljendatakse agentsust ning milliste tunnuste kaudu neid protsessis määratletakse. Protsessi osalejate rollide kaudu selgitan, milliste tegevuste ja asjaoludega neid seostatakse, kuidas keeleliselt väljendatakse rolle, mida nad on tekstis tegema pandud. Nimelt kirjutatakse faktide paigutuse ning vaatepunkti valikuga teksti sisse ka teksti koostaja suhtumisi: lausete keelelised valikud osutavad, kelle poolt või vastu kirjutaja 
selles tekstis on, millisesse rühma ta tunneb ennast kuuluvat, millisesse rühma ta eeldab lugejat kuuluvat (Kasik 2008: 18-20).

Tegevused eeldavad tegijaks inimest ehk agenti, kes võib olla tagaplaanil või jääda ka varjatuks (Leeuwen 1996). Lausesemantiline analüüs näitab, millal kajastab lause tegevust või tegu, mis on agentsed, ning millal protsessi või juhtumit, mis on automaatsed. Agentiivsus tähendab "Eesti keele grammatika II" järgi agendi ehk situatsiooni suhtes aktiivse, seda kontrolliva osalise olemasolu situatsioonis. Tunnuste duratiivne/momentaanne ja agentiivne/mitteagentiivne alusel liigituvad dünaamilised situatsioonid tegevusteks (agentiivsed duratiivsed situatsioonid), protsessideks (mitteagentiivsed duratiivsed situatsioonid), tegudeks (agentiivsed mitteduratiivsed situatsioonid) ning juhtumiteks (mitteagentiivsed mitteduratiivsed situatsioonid) (EKG II: 24). Seega liigitub lause Auto sõitis jalakäijale otsa tegevuse, lause Jalakäija jäi auto alla teo ning lause Ülekäigurajal juhtus õnnetus juhtumi alla.

Lauseid, milles tegevussubjekt esineb grammatilise subjektina, nimetatakse aktiivlauseteks, lauseid, kus selline vastavus puudub, aga passiivlauseteks. Subjektita konstruktsiooni käsitlemine passiivi alaliigina rajaneb eeldusel, et tegumoe vahetus põhineb eelkõige püüdel vältida mingitel kaalutlustel tegija esiletõstmist ning tegevuse vaatlemist tegevusobjekti aspektist on selle vahetuse võimalikke kaasnähtusi. (EKG II: 30) Kui liiklusteadetes väidetakse, et jalakäija jääb auto alla, siis välditakse lauses otsasõitja esiletõstmist ning sündmust kirjeldatakse autojuhi vaatepunktist. Kui aga auto sõidab jalakäijale otsa, siis protsessi aktiivne osaline on auto (kuigi peaks olema autot juhtiv inimene), jalakäija roll on jäetud passiivseks.

Uuringus vaatlen, kelle vaatepunktist sündmusi raamistatakse, kes saab rääkida, kellel on võimalus sõnastada, mis toimus ja mis põhjustel toimus, kes on vaikiv hääl. Järeldusi teen järgmiste põhimõtete järgi: kui kasutatakse nt väljendeid ootamatult teele jooksnud, helkur polnud nähtav, siis on olukorda kirjeldatud juhi vaatepunktist. Nimelt tuli jalakäija ülekäigurajale juhile ootamatult ning juht ei näinud helkurit, mida jalakäija tegelikult kandis. Analüüsin, kuidas pea- ja kõrvallausetega tähendusi edasi antakse, kuidas väljendatakse agentsust, kelle eksimustele tekstis osundatakse ning milliste keeleliste valikutega seda tehakse.

Uurimismaterjaliks on siseministeeriumilt maanteeametile esitatud 2013. aasta oktoobri-novembri 26 liiklusteadet, mis kajastasid õnnetusi olukorras, kus jalakäijal oli eesõigus ehk õnnetused toimusid reguleeritud või reguleerimata ülekäigurajal. Igahommikused liiklusteated paneb prefektuuridest tulnud lühikirjelduse põhjal kokku Politsei- ja Piirivalveameti korrapidaja (Härson 2014). Oktoobri ja novembri teated valisin põhjusel, et sel perioodil suurenes õnnetuste arv ülekäiguradadel ning oli erinevaid juhtumeid: nendes näidetes esines õnnetusi nii laste kui ka vanemate inimestega, samuti oli surmaga lõppenud õnnetusi ning viiteid helkuri puudumisele. Oluline oli ka asjaolu, et sarnaseid sündmusi esitati erinevas sõnastuses.

Et selgitada, kas need osatulemused on kooskõlas lugejaarvamuse uurimusega, viisin uuringu teises etapis läbi küsitluse selgitamaks, kuidas liiklusteadete lugejad tajuvad süüdlast. Palusin 104 uuringus osalejal hinnata nende 26 liiklusteate sõnastusi. Liiklusteadete kirjapilt oli muutmata. Kui ühel päeval oli kaks õnnetust, siis nummerdasin need teate esinemise järjekorras: nt 28. okt (2). Vastajad olid vanuses 17-50, nendest kolmandik oli põhi-, kolmandik kesk- ning kolmandik kõrgharidusega. Vastajatest oli mehi 45, naisi oli 59. Vastajate hulgas oli nii 
autojuhte kui ka juhiloata inimesi. Liiklusteate sõnastuse põhjal palusin määrata, kes on õnnetuses süüdlane (tõmmata liiklusõnnetuse osalejale joon alla). Kui vastajad märkisid süüdlaseks nii autojuhi kui ka jalakäija, läksid mõlemad vastused arvesse.

Järgnevas peatükis esitan tekstianalüüsi koos näidetega, mis pärinevad siseministeeriumi liiklusteadetest. Analüüsiosa iga peatükk sisaldab kõrvuti mõlema uurimisetapi tulemusi: nii kriitilise diskursuseanalüüsi tekstinäited ja järeldused kui ka küsitluste tulemused selle kohta, kuidas lugejad tajuvad liiklusõnnetuste süüdlasi. Küsitluste tulemused on esitatud eraldi kolmel graafikul.

Esmalt on peatükis 3.1. sündmuste agentsuse lingvistiline analüüs. Järgneb sündmuste asjaolude esitus ning vaatepunkti analüüs: materjal on liigendatud esile kerkinud aladiskursuste kaudu, milleks on jalakäija eksimuste diskursus, surmaga lõppenud liiklusteated ning õnnetused lastega.

\section{2013. aasta oktoobri- ja novembrikuu liiklusteadete analüüs}

\subsection{Kas juht sõitis otsa või jalakäija sai autolt löögi?}

Lausetasandi analüüsis selgitan, millised tähendused esitatakse pealauses ning millised kõrvallause(te)s, kuidas väljendatakse agentsust. Kõikides oktoobri- ja novembrikuu liiklusteadetes nimetatakse pealauses, millisel ajahetkel ning kus õnnetus toimus ehk sündmus on esitatud juhtumina, kus tegutsejad, seega ka vastutajad puuduvad.

Esimese astme kõrvallaused olid oktoobri-ja novembrikuu uudistes sõnastatud peamiselt kahel viisil. Esimese raamistuse kohaselt (1. okt näide) saame esimese astme kõrvallauses teada, et auto sõitis jalakäijale otsa. Selliseid liiklusteateid oli oktoobris 9 ning novembris 4 . Teise astme kõrvallauses lisatakse sündmuse agent: öeldakse juhi vanus ja eesnimi. Uudise viimane lause on passiivlause: jalakäija toimetatakse ära. Seega on liiklusteade sõnastatud viisil, kus sündmuses osalevad auto ning jalakäija: täpsemalt sõidab auto jalakäijale otsa.

(1) 1. oktoobril kell 16.00 toimus liiklusõnnetus Tallinnas Pärnu maantee 238 juures, kus maastur Mercedes-Benz ML 270, mida juhtis 38-aastane Vadim, sõitis reguleerimata ülekäigurajal otsa teed ületanud 51-aastasele Enele. Jalakäija toimetati Põhja-Eesti Regionaalhaiglasse.

Teise raamistuse kohaselt saabjalakäija autolt löögi (7. okt näide). Selliseid teadete sõnastusi oli oktoobris 2 ning novembris 11, seega on liiklusteadete sõnastusviis novembris võrreldes oktoobriga muutunud.

(2) 7. oktoobril kella 07.59. ajal toimus liiklusõnnetus Harjumaal Maardus Keemikute 25juures, kus reguleerimata jalakäijate ülekäigurajal sõiduteed ületanud 40-aastane Natalja sai löögi seni kindlakstegemata punast värvi kaubikult. Peale liiklusõnnetust aitas kaubiku juht jalakäija bussipeatusesse istuma ning lahkus seejärel sündmuskohalt. Jalakäija toimetati Ida-Tallinna Keskhaiglasse. 
Järgnevalt kontrollisin küsitluse vastuseid, et hinnata, kas need kaks erinevat raamistust, kus üks on väljendatud tegevusena (auto sõidab otsa) ning teine teona (jalakäija saab autolt löögi), on mõjutanud ka vastajate hoiakuid. Selleks et tulemused oleksid võrreldavad, valisin ainult need uudised, kus pole lisainfot helkuri, alkoholi, ilmaolude, surma või muu kohta. Mõlemat raamistust esines kuuel korral. Nende 12 näite puhul võrdlesin, kas vastajad tajusid eri sõnastuste puhul liiklusonnetuse süülisi erinevalt (joonis 1).

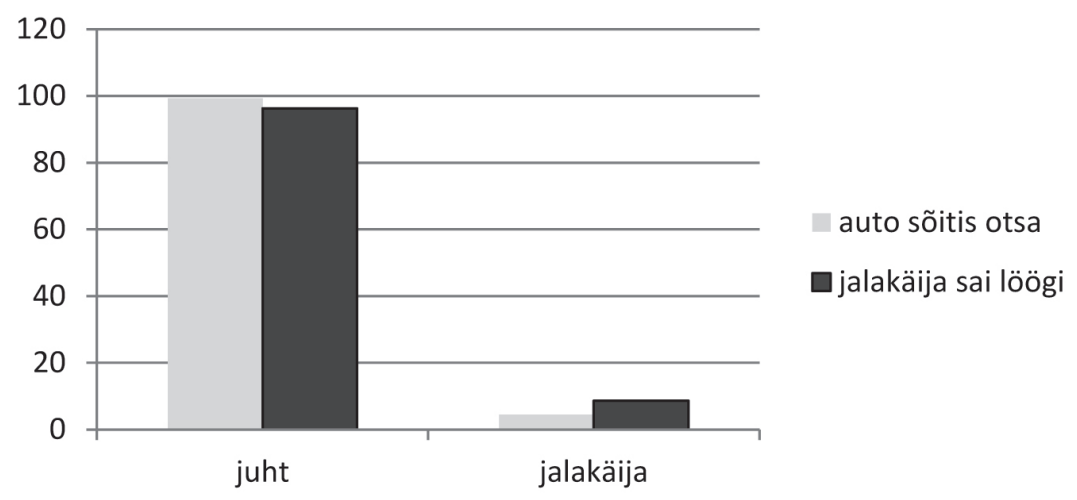

Joonis 1. Vastajate poolt märgitud süüdlane (juht või jalakäija) liiklusteadetes kasutatud väljendite auto sõitis jalakäijale otsa ning jalakäija sai autolt löögi korral

Nendel juhtumitel, kus sõnastuse kohaselt auto sõitis ülekäigurajal jalakäijale otsa, märgiti juhti süüdlaseks keskmiselt 99,5 korda ning jalakäijat 4,5 korral. Kui sõnastuses esines väljend, mille kohaselt jalakäija sai lïklusvahendilt löögi, märgiti juhti süüdlaseks keskmiselt 96 korral ning jalakäijat 8 korral. Seega kui jalakäijat esitatakse situatsiooni suhtes aktiivses rollis, suureneb nende vastajate osakaal, kes näevad jalakäija süüd suuremana ning autojuhi süüd väiksemana.

\subsection{Jalakäija eksimuste diskursus}

Liiklusteadetes eristuvad omaette diskursusena sõnumid, kus juhitakse tähelepanu asjaoludele, mille vastu oli eksinud jalakäija, ning nendele asjaoludele, mis takistas juhti jalakäijat ülekäigurajal märkamast. Oktoobrikuu uudistes on kahel korral lisatud helkuri puudumine (28. okt 1. uudis ja 30. okt näide).

(3) 28. oktoobril (1) kella 17.05 ajal toimus liiklusõnnetus Jõhvis Pargi tänaval ajutisel reguleerimata ülekäigurajal, kus sõiduauto Audi 8o, mida juhtis 55-aastane Alesha, sõitis otsa sõiduteed ületanud jalakäijale, kellel puudus nõuetekohane helkur. 37-aastane Aljona toimetati Ida-Viru Keskhaiglasse.

Selliste liiklusteadete sõnastuses ei ole ühtegi viidet neile tunnustele, mille vastu võis eksida juht (nt milline oli kiirus või kas juht rääkis telefoniga vms). Samuti pole arusaadav, kas kõigis ülejäänud õnnetustes kandsid jalakäijad helkurit või heledaid riideid.

Oktoobrikuu uudistes esines ka näide (30. okt), kus helkuri puudumine, jalakäija vanus ning äratoimetamine paigutatakse ühte lausesse. Jalakäija identiteet konstrueeritakse vanuse ning helkuri mitteomamise kaudu. 
(4) 30. oktoobril kella 17.39 ajal toimus liiklusõnnetus Võrus Jüri tänaval reguleerimata ülekäigurajal, kus sõiduauto Opel Astra, mida juhtis 23-aastane Elar, sõitis otsa sõiduteed ületanud jalakäijale. Helkurit mitte kandnud 49-aastane Ave toimetati Võru haiglasse.

Joonisel 2 on 104 vastaja hinnang oktoobrikuu õnnetuste süüdlase kohta. Neis liiklusteadetes, kus jalakäija eksimustele ei viidatud (1.-25. okt, 28 okt), tajusid vastajad süüdlasena valdavalt juhti. Kui uudiste sõnastuses on mainitud, et jalakäija ei kandnud helkurit (28. (1) ja 30. okt, vt näide (3) ja (4)), suurenes oluliselt nende vastajate arv, kelle hinnangul oli õnnetuses süüdlane jalakäija.

7. okt (näide 2) uudisesõnastuse kohaselt aitas kaubikujuht jalakäija bussipeatusesse istuma ning lahkus seejärel sündmuskohalt. Selle lisainfo mõjul suurenes nende vastajate arv, kes märkisid süüdlaseks jalakäija. Seda hoolimata asjaolust, et sündmuskohalt lahkunud juhi süü on oluliselt suurem kui sündmuskohale jäänud juhi süü. Vaid ühes uudises (29. okt) ei märgitud süüdlasena jalakäijat: nimelt sõitis selles liiklusteates üks autojuht teisele autojuhile ülekäigurajal otsa.

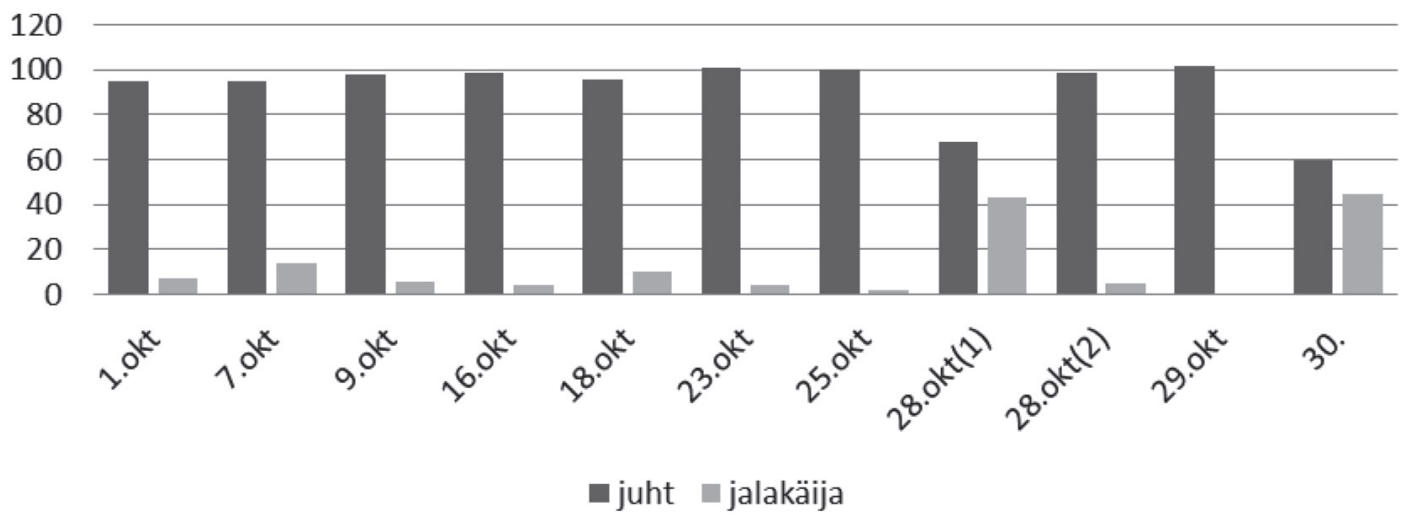

Joonis 2. 104 küsitletava hinnang oktoobrikuus ülekäigurajal toimunud liiklusõnnetuse süüdlase kohta liiklusteadete põhjal. 28. okt 1. uudises ja 30. okt uudises on viide jalakäija helkuri puudumisele

Liiklusteadetes on ohver vaikiv hääl, tema versiooni juhtunust pole kuulda. Jalakäija toimetatakse ära. Õnnetuse põhjustaja saab seletuskirjas olukorda kirjeldada enda vaatepunktist. Isegi kui jalakäija kannab helkurit, ei pruugi see olla otsasõitja hinnangul piisav (nt 20. novembri 2. uudis).

(5) 20. novembril (2) kella 17.02 ajal toimus liiklusõnnetus Haapsalus Tallinna maantee 4 juures, kus reguleerimata ülekäigurajal sõiduteed ületanud 59-aastane Tatjana sai löögi sõidukilt Ford Transit, mida juhtis 40-aastane Arvo. Jalakäija toimetati kiirabi poolt Läänemaa Haiglasse kontrolli. Jalakäijal oli helkur kinnitatud käekoti külge kuid jäi autojuhi jaoks varjatuks, samuti pimestasid vastu tulevate sõidukite tuled autojuhti.

Selline autojuhipoolne sündmuse kirjeldus võimaldab uudisesse lisada rohkesti lisainfot, mis soodustas otsasõitu. Nii on liiklusteated sõnastatud juhi vaatepunktist ning selline liiklusteadete raamistus on kooskõlas lugejaarvamuse uuringuga: ka lugejad interpreteerivad liiklusteateid autojuhile soodsamal viisil. 


\subsection{Surmaga lõppenud õnnetuste liiklusteated}

Sama tendents on täheldatav ka surmaga lõppenud õnnetusjuhtumites. Kui liiklusteadetes (23. okt näide, vt ka 2. joonis) pole lisafakte jalakäija kohta, siis ei märkinud enamik uudise lugejaid süüdlaseks jalakäijat (102 korral märgiti süüdlaseks juht).

(6) 23. oktoobril kella 15.50 ajal toimus liiklusõnnetus Narva linnas, Kangelaste 29 juures, kus sõiduauto Volkswagen Vento, mida juhtis 22-aastane mees, sõitis otsa reguleerimata ülekäigurajal teed ületavale jalakäijale, 78-aastasele Veerale, kes toimetati Narva Haiglasse, kus ta hiljem suri.

Teistes surmaga lõppenud õnnetuste liiklusteadetes (3. joonisel 5. nov (2), 20. nov (2)) on lisatud info jalakäija tumedatest riietest või helkuri puudumisest. See teave mõjutab, kuidas teksti lugejad tajuvad süülisust: 5 . novembri 2. liiklusõnnetuses märgiti 66 korral süüdlaseks juht, 56 korral jalakäija.

(7) 5. novembril (2) kella 17.30 ajal toimus liiklusõnnetus Narvas Kadastiku tänaval, kus sõiduauto Peugeot 307, mida juhtis 57-aastane Juri sõitis otsa reguleerimata ülekäigurajal sõiduteed ületanud jalakäijale. Jalakäija 66-aastane Anatoli toimetati Narva Haiglasse. Jalakäija oli riietatud tumedatesse riietesse ja tal puudus helkur. Jalakäija suri haiglas.

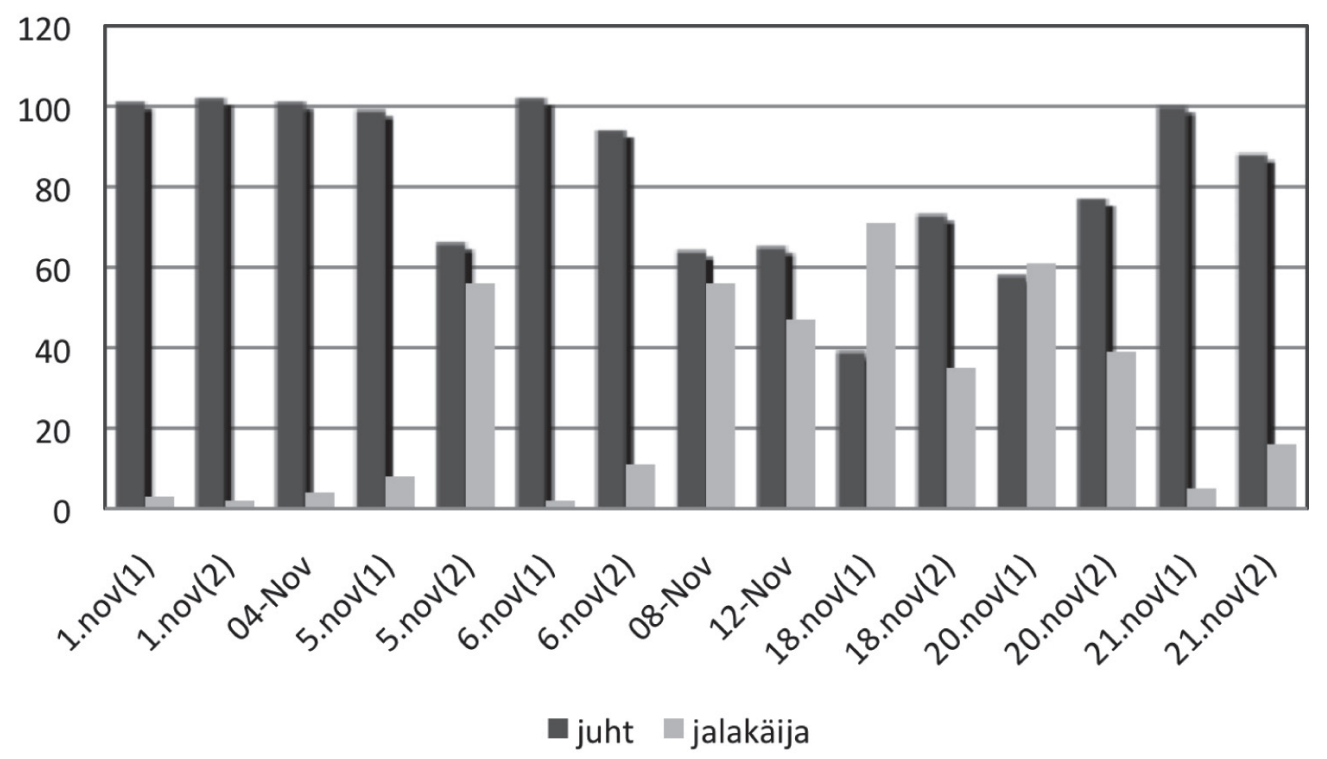

Joonis 3. 104 küsitletava hinnang novembrikuus ülekäigurajal toimunud liiklusõnnetuse süüdlase kohta liiklusteadete põhjal

20. novembri 1. uudises oli neid vastajaid rohkem (vt ka joonis 3), kes märkisid jalakäija süüdlaseks: nimelt 58 vastajat märkisid süüdlaseks juhi ning 61 korral märgiti süüdlaseks jalakäija. Näites on esitatud loetelu selle kohta, kuidas keskkond mõjutas juhti ning lõpuks ka viide helkuri puudumisele. 
(8) 20. novembril (1) kella 07.00 ajal toimus liiklusõnnetus Tallinnas Paldiski maantee 227juures, kus esialgsetel andmetel reguleerimata ülekäigurajal sõiduteed ületanud 70-aastane Galina sai löögi sõiduautolt Peugeot 206, mida juhtis 35-aastane Jüri. Jalakäija hukkus sündmuskohal. Õnnetuse hetkel oli pime, sadas vihma, teepind oli märg. Jalakäijal helkurit ei olnud.

Jalakäija kohta esitatud lisafaktid liiklusteadete sõnastustes kujundavad lugejate hoiakuid, ka jalakäija surm ei mõjuta olulisel määral vastajate hoiakuid. Mida rohkem on sõnastuses asjaolusid, mis selgitavad juhi seisukohalt raskendavaid asjaolusid (halvad ilmaolud, jalakäija helkuri puudumine), seda vähem tajuvad uudise lugejad, et juht oli liiklusõnnetuse põhjustaja. Seda hoolimata asjaolust, et seaduse järgi tohib helkurita jalakäija ja ka tumedates riietes jalakäija ülekäigurajal teed ületada.

\section{4. Õnnetused lastega}

18. novembri uudistes paistab silma kaks ühel päeval lastega toimunud õnnetust, kus selgelt eristub, kuidas sündmuse sõnastus mõjutab vastajaid. Esimese teate sõnastusele ootamatult jalakäijate ülekäigurajale jooksnud 12-aastane poiss sai löögi (vt ka 3. joonise 18. nov 1. õnnetus) märgiti 39 korral süüdlaseks juht ning 71 korral märgiti süüdlaseks jalakäija.

(9) 18. novembril (1) kella o8.50 toimus liiklusõnnetus Tallinnas Paekaare 50 juures, kus ootamatult jalakäijate ülekäigurajale jooksnud 12-aastane poiss sai löögi sõiduautolt Renault Megane, mida juhtis 25-aastane Roman. Jalakäija toimetati Tallinna Lastehaiglasse.

Teises 18. novembri uudises on kasutatud neutraalsemaid väljendeid, mille kohaselt tõukerattaga sõiduteed ületanud 8-aastane poiss sai löögi. Sellise sõnastuse puhul märgiti 73 korral süüdlaseks juht ning 35 korral jalakäija (vt ka 3. joonise 18. nov 2. õnnetus).

(10) 18. novembril (2) kella 13.0o ajal toimus liiklusõnnetus Tallinnas Telliskivi 20 juures, kus reguleerimata jalakäijate ülekäigurajal tõukerattaga sõiduteed ületanud 8-aastane poiss sai löögi sõiduautolt Mercedes-Benz, mida juhtis 44-aastane Marika. Laps toimetati Tallinna Lastehaiglasse.

Väljend jooksis ootamatult ülekäigurajale on sõnastatud autojuhi vaatepunktist ning suurendab oluliselt nende vastajate osakaalu, kes näevad õnnetuse põhjustajana jalakäijat. Liiklusseaduse kohaselt peab autojuht liikluses arvestama ka lastega. Sõnastustega sõiduteed ületanud või ootamatult jalakäijate rajale jooksnud saab teksti koostaja selgelt kujundada lugejate hoiakuid, luues uudiste keelekasutusega ka selle tõlgendust. 


\section{Järeldused ja diskussioon}

Liiklusteadete pealaused on passiivlaused ning sõnastatud lausesemantiliste tunnuste agentiivne/mitteagentiivne alusel juhtumina (õnnetused toimuvad), mitte tegevuste, protsesside ega tegudena. Liiklusteadete esimese astme kõrvallausetes on aktiivsed osalised jalakäija otsa sõitvad autod, ning sõidukilt löögi saanud jalakäijad. Autojuhti nimetatakse teise astme kõrvallauses. Uudised on raamistatud juhi vaatepunktist, millest tulenevalt on sõnumi fookuses eelkõige need aspektid, miks juht ei näe ülekäigurajal jalakäijat, mis segas ja takistas autojuhti.

Selline uudiste raamistus on kooskõlas lugejaarvamuse uuringuga: lugejad interpreteerivad liiklusteateid autojuhile soodsamal viisil. Mida rohkem sõnastati asjaolusid, mille vastu eksis jalakäija (helkuri puudumine, tumedad riided) või mis segasid autojuhti ülekäigurajal (halb nähtavus), seda rohkem tajuti süüdlasena jalakäijat. Juhi vaatepunkti lisamine liiklusteate sõnastusse (sõiduteed ületanud asemel ootamatult ülekäigurajale jooksnud) mõjutab oluliselt lugejate hoiakuid.

Sellisel liiklusteadete diskursusel on mitmeid põhjusi. Ühe selgituse kohaselt on inimesed, kes sündmusi konstrueerivad ning uudiseid loovad, empaatilisemad nende suhtes, kes olid otsasõitjad, ning vähem kaastundlikud ohvrite suhtes, kuna suheldakse autojuhtidega ning ohvritega pole enam kokkupuudet. Tekstide koostajate jaoks on uudiste koostamine rutiinne tegevus, mida tehakse välja kujunenud diskursuse korra järgi. Selliseid tekste koostatakse usus, et nad teenivad liikluskasvatuse eesmärke. Tuuli Härson (2014: 38) väidab: “Kuupäev, kellaaeg, koht ja perfektselt tasakaalus osaliste loetelu - neid teateid oleks lihtne kokku panna, aga mis oleks selle mõte? Kui küsida mis tahes olukorras, kes on süüdi, siis küll see süüdlane leitakse. Kui tahame käitumist muuta, siis peab olema teates midagi, millest õppida.” Politsei lähtub Härsoni (ibid.) hinnangul põhimõttest, et “iga infokild, mis aitab õnnetust ära hoida, on äramärkimist väärt. Hukkunutega õnnetuste korral mobiliseerime end võimalikult kiiresti, et pressiteate vormis edastada iga õnnetuse taga olevat lugu, mis inimesi kõnetab.” Seega lähtuvad liiklusteadete kirjutajad usust, et nende eesmärk on eelkõige liiklejaid õpetada.

Nii jääb kõrvaliseks kõige olulisem asjaolu: autojuhid sõidavad ülekäigurajal jalakäijatele otsa ning inimesi saab surma. Samuti annab see avalikkusele selge sõnumi: ülekäigurajal õnnetusse sattunud jalakäijad on ise süüdi, kui autojuht neid ei näe. Sedasi pannakse ebaproportsionaalselt suur vastutus liikluses nõrgemale poolele. Artikli tulemused on kooskõlas rahvusvaheliste uuringutega, mille kohaselt liiklusõnnetuste diskursuses domineerib autokeskne lähenemine ning autota liiklejad on avalikus ruumis halvemas positsioonis (Freund, Martin 1997, Whatley 1988, Sheller, Urry 2000).

Ka on oluline asjaolu, et liiklusõnnetuse mõiste on liiklusseaduses (2010) sõnastatud kui juhtum ajas ja ruumis, mitte tegevus ega tegu. Seaduses ei nähta vigastust ega surma personaalsena, küll aga juhtumina. Seetõttu lähtub teate edastanud korrapidaja Eesti legaalsest kontekstist. Kuni pole kindlaks tehtud teisiti, on kellegi surm õnnetusjuhtumi tagajärg, mistõttu ei saaks liiklusteadet ka agentselt esitada. Seega peaks lugejaarvamus viitama asjaolule, et legaalne kontekst suunab kirjutaja kaudu ka lugejat. Nii on tähenduse konstrueerimine keerukam protsess, kui käesolev artikkel suudab kirjeldada. Küll tõestas lingvistiline analüüs selgesti, et liiklusteated on kaldu autojuhi õigustamise suunas ja unustavad legaalse konteksti: ülekäigurajale lähenemise loomuliku legaalse käitumismudeli. 
Kindlasti peavad esmaste liiklusteadete sõnastajad hindama, kas selline meediakajastus on tõesti vajalik ja kas selle tulemusena Eestis liikluskultuur tegelikult ka paraneb. Eestis on seatud eesmärgiks vähendada jalakäijatega juhtunud liiklusõnnetuste arvu 2015. aastaks, sest viiest jalakäijatega juhtunud õnnetusest neli juhtub asulasisesel tänaval, õuealal või parklas (vt Abinõude valik... 2004). Kui liiklusõnnetustes hukkunute arv Eestis on vähenenud, siis jalakäijate puhul on see arv kolme aastaga suurenenud (17,7\% asemel juba 25\%).

Kas senine liikluskommunikatsioon vajaks ümbervaatamist? Olukorra muutmise võimalusena nähakse kaasata jalakäijaid kultuurilise tähenduse loomise protsessi ja tõsta nende mõjuvõimu ühiskonnas. Selleks peab jalakäijate kogukond senisest oluliselt rohkem kaasa rääkima nii kultuuri, kogukonna kui ka turvalisuse küsimustes (Demerath, Levinger 2003). Ühiskonnas on oluline luua tasakaalustatud dialoog, et liikluskultuuri kujundamisel arvestataks kõikide huvigruppide, ka jalakäijate, jalgratturite ning teiste gruppide, seisukohadega.

Üheks lahenduseks oleks liikluskasvatust ning liiklusõnnetusi kajastavate teadete selge lahushoidmine. Liiklusteadetele kehtiksid meediaeetika reeglid, mille kohaselt ei tohi sündmuste kajastamisel asuda kellegi poolele, kallutada avalikku arvamust ühes või teises suunas (Eetikakoodeks). Kui liiklusteated on edastatud, on alati võimalus pöörata liiklejate tähelepanu turvalisust suurendatavale asjaoludele: helkurile, kiivrile, aga ka õigesti valitud kiirusele, kutsuda liiklejaid üles olema vastastikku tähelepanelikumad, tegema paremat koostööd jne. Õnnetuste ohvrid on liikluses vähem kaitstud osa: eelkõige lapsed ja vanemad inimesed. Jalakäija ja auto kokkupõrkes ülekäigurajal on esimene nõrgemas positsioonis ning sellest on võimalus liikluskommunikatsioonis lähtuda.

\section{Viidatud kirjandus}

Abinõude valik jalakäijate ja jalgratturitega toimunud liiklusõnnetuste ning neis kannatanute arvu vähendamiseks: II etapp. [Improvement of road safety situation of vulnerable road users - pedestrians and bicyclists.] Lõpparuanne. Tallinn: Maanteeamet, 2004. http://www.mnt.ee/failid/Kergl.pdf (5.5.2014).

Demerath, Loren; Levinger, David 2003. The social qualities of being on foot: A theoretical analysis of pedestrian activity, community, and culture. - City \& Community, 2 (3), 217-237. http://dx.doi.org/10.1111/1540-6040.00052

Dijk, Teun A. van 2005. Ideoloogia. Multidistsiplinaarne käsitlus. [Ideology: A Multidisciplinary Approach.] Tartu: Tartu Ülikooli Kirjastus.

Eetikakoodeks. [Code of Ethics.] Eesti Ajalehtede Liit. http://www.eall.ee/eetikakoodeks. html (27.9.2014).

EKG II = Erelt, Mati; Kasik, Reet; Metslang, Helle; Rajandi, Henno; Ross, Kristiina; Saari, Henn; Tael, Kaja; Vare, Silvi 1993. Eesti keele grammatika II. Süntaks. [Estonian Grammar II. Syntax.] Tallinn: Eesti Teaduste Akadeemia Keele ja Kirjanduse Instituut.

Fairclough, Norman 1989. Language and Power. London: Longman.

Fairclough, Norman 1991. Discourse Processes and Social Change. Cambridge: Polity Press. Fairclough, Norman 1992. Discourse and Social Change. Cambridge: Polity Press.

Fairclough, Norman 1995. Critical Discourse Analysis: The Critical Study of Language. Harlow: Longman.

Fairclough, Norman 2001. Language and Power. Second edition. Harlow: Longman.

Fairclough, Norman 2005. Critical discourse analysis in transdisciplinary research. R. Wodak, P. Hilton (Eds.). A New Agenda in (Critical) Discourse Analysis. Amsterdam: John Benjamins Publishing Company, 53-70. 
Fairclough, Norman; Wodak, Ruth 1997. Critical discourse analysis. - Teun van Dijk (Ed.). Discourse as Social Interaction. London: Sage, 258-284.

Flowerdew, John 1999. Description and interpretation in critical discourse analysis. - Journal of Pragmatics, 31 (8), 1089-1099. http://dx.doi.org/10.1016/S0378-2166(99)00049-1

Freund, Peter E. S.; Martin, George T. 1997. Speaking about accidents: The ideology of auto safety. - Health, 1 (2), 167-182.

Harvey, Lee; Macdonald, Morag 1993. Doing Sociology: A Practical Introduction. Macmillan Distribution.

Huckin, Thomas 1997. Critical discourse analysis. - Tom Miller (Ed.). Functional Approach to Written Text: Classroom Application. Wachington. http://files.eric.ed.gov/fulltext/ ED417422.pdf\#page $=87$ (15.7.2014).

Härson, Tuuli 2014. Liikluskommunikatsioon: sõnaga surma vastu. - Kaja, 15, 37-38.

Kasik, Reet 2008. Meediateksti analüüs: eesmärgid ja metoodika. [Analysis of the media texts: Aims and methods.] - Reet Kasik (Toim.). Tekstid ja taustad V. Tartu: Tartu Ülikooli Kirjastus, $10-43$.

Laherand, Marika 2008. Kvalitatiivne uurimisviis. [Quantitative Methods.] Tallinn: OÜ Infotrükk.

Leeuwen, Theo van 1996. The representation of social actors. - Carmen Rosa CaldasCoulthard, Malcolm Coulthard (Eds.). Texts and Practices: Readings in Critical Discourse Analysis. London: Routledge, 32-70.

Liiklusseadus 2010. [Traffic Act.] https://www.riigiteataja.ee/akt/102072013012 (29.6.2014).

McQuail, Denis 2000. McQuaili massikommunikatsiooni teooria. [McQuail's Mass Communication Theory.] Tartu: Tartu Ülikooli Kirjastus.

Oatman-Stanford, Hunter 2014. Murder machines: Why cars will kill 30,000 Americans this year. http://www.collectorsweekly.com/articles/murder-machines/ (28.7.2014).

Pan, Zhondang; Kosicki, Gerald M. 2010. Framing analysis: An approach to news discourse. Political Communication, 10 (1), 55-75. http://dx.doi.org/10.1080/10584609.1993. 9962963

Roberts, Ian; Wentz, Reinhard; Edwards, Phil 2006. Car manufacturer and global road safety: A word frequency analysis of road safety documents. - Injury Prevention, 12 (5), 320-322. http://dx.doi.org/10.1136/ip.2006.012849

Sheller, Mimi; Urry, John 2000. The city and car. - International Journal of Urban and Regional Research, 24 (4), 737-751. http://www.livingrail.eu/images/pdf/2000 sheller urry the city and the car.pdf (20.8.2014).

Serafini, Frank 2003. Informing our practice: Modernist, transactional, and critical perspectives on children's literature and reading instruction. - Reading Online, 6 (6). http://www.readingonline.org/articles/art index.asp?HREF=serafini/index.html (12.8.2012).

Vallières, Lucie 2006. Disciplining Pedestrians? A Critical Analysis of Traffic Safety Discourses. MA thesis. Simon Fraser University.

Whatley, Marianne H. 1988. Raging hormones and powerful cars: The construction of men's sexuality in school sex education and popular adolescent films. - Journal of Education, 170 (3), 100-121.

Widdowson, Henry G. 1998. The theory and practice of critical discourse analysis. - Applied Linguistics, 19 (1), 136-151. http://dx.doi.org/10.1093/applin/19.1.136

Wodak, Ruth 1996. Disorders of Discourse. London-New York: Longman.

Katrin Aava (Tallinna Ülikool) peamised uurimisvaldkonnad on meediatekstide, haridustekstide kriitiline diskursuseanalüüs.

Narva mnt 29, 10120 Tallinn, Estonia

aava@tlu.ee 


\section{WHO'S RESPONSIBLE? THE LINGUISTIC \\ CONSTRUCTION OF PARTICIPANTS \\ IN TRAFFIC ACCIDENTS}

Katrin Aava

Tallinn University

Reports on traffic accidents carry societal meanings and judgements about the value of human life, role and responsibility of all parties and who is to be blamed. Critical discourse analysis used in this research is a method that allows to detect such hidden meanings of societal agreements and interpretations encoded in texts. To exemplify how the roles of different parties are construed in traffic news, were analysed 26 police reports about traffic accidents that happened on crossroads in October and November 2013. To find out how such framing influences readers in interpreting the text, were questioned 104 respondents.

The text analysis showed that traffic news stories are being framed through the driver's viewpoint and attention is drawn to the pedestrian's mistakes (lack of a reflector, dark clothing). Traffic reports are phrased in such a way that accidents happen, their active participants are cars which hit pedestrians and pedestrians who are hit by cars. The questionnaire revealed that the more emphasis is put on the factors that distracted the driver, the more readers perceive pedestrians as responsible for the accident.

Keywords: critical discourse analysis, framing, viewpoint, traffic reports 